\title{
INTRODUCING THE CRIMEAN OUT-OF-HOSPITAL CARDIAC ARREST AND RESUSCITATION REGISTRY (COHCARR): RATIONALE, DESIGN AND 6-MONTH BASELINE DATA
}

Alexei Birkun', Lesya Frolova²

\section{Sažetak}

\section{Uvods}

Postoji potreba za uspostavljanjem registara za vanbolnički srčani zastoj (OHCA) u zemljama bivšeg Sovjetskog Saveza. Ovaj članak ima za cilj pružiti obrazloženje i opisati metodologiju krimskog registra vanbolničkog srčanog zastoja i oživljavanja (COHCARR), te izvijestiti osnovne podatke o epidemiologiji OHCA i hitnoj medicinskoj službi (EMS) u Republici Krim. Metode: COHCARR je zamišljen kao potencijalni populacijski registar svih slučajeva OHCA-e koji su prisustvovali EMS-u sa pokušajima oživljavanja koji se događaju u Republici Krim. Pokrivenost stanovništva je 1,91 miliona (100\% stanovnika republike). Osnovna opisna analiza OHCA s pokušajem reanimacije (1. siječnja-30. lipnja 2018.) provedena je po Utstein metodologiji kako bi se dao sažetak problema OHCA u regiji.

\section{Rezultati:}

U tom periodu, EMS je prisustvovalo ukupno 6391 OHCA. S tim je reanimacija pokušana samo u 196 slučajeva (3,1\%; srednja dob 65 godina, muškarci 56\%, šokantna 16\%). Većina (95\%) svjedočila je EMS ili prolaznik. Od slučajeva svjedoka koji su prolazili $(24 \%, n=47)$, pokušaj reanimacije pokušao je u $19 \%$ (n = 9). Povratak spontane cirkulacije (ROSC) postignut je u 6,6\% bolesnika, a 5,6\% je preživelo prijem u bolnicu.

\section{Zaključci:}

Niske stope pokušaja oživljavanja, ROSC i preživljavanje do prijema u bolnicu nalažu priliku za poboljšanje ishoda OHCA na Krimu. Registar će pomoći ciljanju razumnih isplativih intervencija i procjeni njihove učinkovitosti u regiji. COHCARR može poslužiti kao osnovni model za izradu registra OHCA na drugim postsovjetskim teritorijama.

\section{Abstract \\ Introduction:}

There is an urgent unmet need for establishing out-of-hospital cardiac arrest (OHCA) registries in the former Soviet Union countries. This article aims to provide a rationale and describe methodology of the Crimean out-of-hospital cardiac arrest and resuscitation registry (COHCARR), and report baseline information on OHCA epidemiology and emergency medical service (EMS) performance in the Republic of Crimea.

Methods: COHCARR is designed to be a prospective population-based registry of all EMS-attended OHCA cases with resuscitation attempts, occurring in the Republic of Crimea. The population coverage is 1.91 million (100\% inhabitants of the republic). The baseline descriptive analysis of OHCA with attempted resuscitation (January 01-June 30, 2018) has been performed following the Utstein methodology to provide a snapshot of OHCA problem in the region.

\section{Results:}

During the period, a total of 6,391 OHCA were attended by EMS. With that, resuscitation was attempted only in $196 \mathrm{ca}-$ ses (3.1\%; median age 65 years, male $56 \%$, shockable $16 \%$ ). Most (95\%) were witnessed by EMS or a bystander. Out of the bystander-witnessed cases $(24 \%, n=47)$, bystander resuscitation was attempted in $19 \%(n=9)$. Return of spontaneous circulation (ROSC) was achieved in $6.6 \%$ patients, and $5.6 \%$ survived to hospital admission.

\section{Conclusions:}

The low rates of attempted resuscitation, ROSC and survival to hospital admission imply an opportunity to improve outcomes from OHCA in the Crimea. The registry will help to target reasonable cost-effective interventions and assess their effectiveness in the region. COHCARR may serve as a basic model for developing OHCA registries in other post-Soviet territories.

\section{USTANOVA}

Medical Academy named after S. Georgievsky of V. I. Vernadsky Crimean Federal University; 295051, Simferopol, Russian Federation;

Crimean Republican Center for Disaster Medicine and Emergency Medical Services; 295024, Simferopol, Russian Federation

\section{AUTOR ZA} KORESPODENCIU:

Alexei Birkun

email: birkunalexei@gmail.com
KLJUČNE REČl:

Srčani zastoj, kardiopulmonalna reanimacija, Registar, Utstajn, Hitne medicinska pomoć

\section{KEY WORDS:}

Cardiac arrest; Cardiopulmonary resuscitation; Registry; Utstein,

Emergency medical services.
DATUM PRIJEMA RADA

23.12.2019. DatUM PRIhUATANua Rada 26.12.2019. Datum OBjavlunanja 30.12.2019. 


\section{Introduction}

Out-of-hospital cardiac arrest (OHCA) is currently recognized as a major health problem worldwide.[1-3] Being widely variable among communities, OHCA survival is known to be closely reflective of the performance of pre-hospital emergency care systems, and OHCA case was recommended to be a reportable event more than a decade ago.[4]

Cardiac arrest registry is universally acknowledged to be an essential tool for the public health surveillance with a final goal of improving quality of care and survival from cardiac arrest.[3,5] Numerous regional, national and international registries continuously collect data on incidence, management and outcomes of OHCA, supporting reasonable changes in pre-hospital care and potentiating resuscitation research.[1-3,5]

Very little is known about the epidemiology of OHCA in the post-Soviet states - the fifteen countries occupying the total area of 22.3 million square kilometers and about one-sixth of the Earth's land surface, covering 11 of the world's 24 time zones and populated with more than 290 million people.[6,7] Scarce studies in selected populations show increased incidence of $\mathrm{OH}$ CA together with low rate of cardiopulmonary resuscitation (CPR) efforts and poor outcomes. $[8,9,10]$ With that, yet there is no organized system for continuous monitoring of epidemiology of OHCA and performance of emergency medical services (EMS) in the former USSR territories. Consequently, there are weak opportunities for clinical benchmarking, collation with international best practices and identification of potential solutions for improving survival.

This paper is aimed to provide rationale and describe methods for the OHCA and resuscitation registry in the Republic of Crimea, as well as to characterize regional EMS system and analyze baseline 6 -month data on OHCA following the Utstein methodology.[11]

\section{Methods}

\section{Aims and design of the registry}

The Crimean out-of-hospital cardiac arrest and resuscitation registry (COHCARR) is designed as a prospective, population-based OHCA registry with the population coverage of 1.91 million, representing $100 \%$ of the population of the Republic of Crimea - inhabitants of 16 cities and 1,003 rural settlements in the Crimean peninsula, located in the Northern Black Sea.[12,13] The registry is not intended to cover the population of the city of Sevastopol, that is geographically located in the Crimean peninsula, but has its own administrative go- vernance and individual EMS system.

The registry is proposed to be established with the following goals:

- to monitor the epidemiology and outcomes of $\mathrm{OH}$ CA, as well as performance of EMS system in the Crimea, and allow for inter-/intrasystem comparisons;

- to identify factors influencing outcomes of OHCA, investigate potential gaps and shortages of the system; - to prioritize and evaluate the effects of new interventions on the outcome, potentiate and guide cost-effective quality improvement processes;

- to support and create new opportunities for resuscitation research.

The Utstein-style guidelines should be followed in order to standardize reporting of the process of care and outcomes for OHCA patients.[11] It is anticipated that the registry will be managed by the State Budgetary Healthcare Institution of the Republic of Crimea «Crimean Republican Center for Disaster Medicine and Emergency Medical Services» (Simferopol) - the central coordinating body of the unified EMS system, comprising seven district-level EMS divisions, covering both urban and rural areas of the region.

\section{Inclusion criteria}

All OHCA cases attended by EMS with CPR attempted should be included into the registry, regardless of cardiac arrest aetiology, initial arrest rhythm, patient gender or age. An OHCA is defined as cessation of cardiac mechanical activity that occurs outside of the hospital setting and is confirmed by the absence of signs of circulation.[11,14]

\section{Data capture process and data elements}

Data on OHCA cases should be collected centrally from the paper source documents of EMS (ambulance callout records and (PR logs) and in-hospital medical records of hospitalized patients, using the standardized electronic OHCA data collection form, and transferred to a Microsoft Access database (Microsoft ${ }^{\circledR}$ Access 2016, Microsoft Corporation, USA). Managers of the district-level EMS divisions are responsible for sending source EMS documents to the data coordinating center in batches, ensuring full coverage of OHCA cases. The hospital-level data should be collected by reviewing patient records from hospital archives with official permission from the hospital administration.

The data should be collected in accordance with the 2014 Utstein consensus definitions, aiming at both core and supplemental Utstein data elements throughout the five data element domains (Table 1).[11] While being included in the data collection form, so far, so- 
me Utstein data elements are expected to be specified as "not applicable" or "not registered", since respective interventions are currently not routinely performed by the EMS or bystanders (e.g. automated external defibrillation). In addition to the Utstein data elements, the following data should be collected for every OHCA case: EMS subdivision identifier, OHCA date and address, time of EMS-witnessed arrest (Table 1).
The EMS response time is defined as a time interval in minutes from incoming call to the time the first EMS vehicle arrives on scene, excepting OHCA cases witnessed by EMS. For EMS-witnessed cardiac arrest, response time should be calculated as a time interval from OHCA recognition by EMS to the start of the resuscitation attempt (usually 0 minutes), while defibrillation and drug timings should be calculated as time intervals

Table 1. A list of data elements to be collected by the Crimean out-of-hospital cardiac arrest and resuscitation registry

\begin{tabular}{|c|c|c|c|}
\hline \multirow{2}{*}{$\begin{array}{l}\text { Data element } \\
\text { domains }\end{array}$} & \multicolumn{3}{|l|}{ Data elements } \\
\hline & Utstein core & Utstein supplemental & Additional \\
\hline System & $\begin{array}{l}\text { Population served } \\
\text { CA attended } \\
\text { Resuscitation attempted } \\
\text { Resuscitation not attempted } \\
\text { System description }\end{array}$ & $\begin{array}{l}\text { System description } \\
\text { (supplemental) }\end{array}$ & EMS subdivision identifier \\
\hline Dispatcher & $\begin{array}{l}\text { Dispatcher-identified CA } \\
\text { Dispatcher CPR instructions }\end{array}$ & - & - \\
\hline Patient & $\begin{array}{l}\text { Age } \\
\text { Gender } \\
\text { Witnessed arrest } \\
\text { CA location } \\
\text { Bystander CPR/AED } \\
\text { First monitored rhythm } \\
\text { Aetiology }\end{array}$ & $\begin{array}{l}\text { Presence of STEMI } \\
\text { Ventricular assist devices } \\
\text { Cardioverter-defibrillator }\end{array}$ & $\begin{array}{l}\text { CA date } \\
\text { CA address }\end{array}$ \\
\hline Process & $\begin{array}{l}\text { Response time } \\
\text { Defibrillation time } \\
\text { Target temperature management } \\
\text { Drugs } \\
\text { Reperfusion attempted }\end{array}$ & $\begin{array}{l}\text { Airway control type } \\
\text { Number of shocks } \\
\text { Drug timings } \\
\text { CPR quality } \\
\text { Vascular access type } \\
\text { Mechanical CPR } \\
\text { Targeted oxygenation, ventilation, } \\
\text { blood pressure } \\
\text { 12-lead ECG } \\
\text { Hospital type and volume }\end{array}$ & Time of EMS-witnessed CA \\
\hline Outcome & $\begin{array}{l}\text { Survived event } \\
\text { Any ROSC } \\
\text { 30-day survival } \\
\text { Survival to discharge } \\
\text { Neurological outcome }\end{array}$ & Transport to hospital & \\
\hline
\end{tabular}

from OHCA recognition by EMS to the first shock and first drug given, respectively.

\section{Data analysis and reporting}

Collected data should be first analyzed descriptively. Chi-square test should be used to reveal differences between categorical variables, and logistic regression analysis - to elicit factors associated with outcomes of OHCA and EMS performance. P-values $<0.05$ are to be considered statistically significant. Official up-to-date population statistics from the Federal State Statistics Service of the Republic of Crimea should be used for calculating the incidence rates. Data on OHCA location must be collected for Geographic Information System (GIS) mapping and analyses.

Results of the data analysis are planned to be provided to the EMS as internal periodical reports for pre-hospital care quality control and quality improvement pur- 
poses, and should also be published in peer-reviewed periodicals.

\section{Ethics}

The registry received an approval from the local Ethical Committee. All data must be depersonalized and no identifiers are to be collected, so there is no risk of compromising patient's confidentiality. A unique identifier should be assigned to each OHCA case after checking for completeness and accuracy of data. As soon as the registry will contain only depersonalized data, no informed consent is deemed to be necessary for data collection. No outside parties may have any access to OHCA case-specific or EMS-specific registry data.

Quality control and assurance

To ensure there are no missing cases, the official total number of resuscitations attempted are proposed to be periodically compared with the actual number of cases included in the registry. Routine audits of random electronic case records should be performed to check for accuracy and completeness. When incomplete data are identified, EMS personnel in charge of the patient must be contacted in order to clarify the missing data before depersonalizing the OHCA case. EMS providers should undergo initial training and continuous education in data collection.

\section{Limitations}

So far, the official ambulance callout form doesn't contain a mandatory field for a bystander CPR reporting, and this information is currently recorded by EMS teams voluntarily as a written comment. Consequently, real bystander CPR rates may be underestimated.

The quality of collected data may be influenced by inappropriate recall and inaccurate registration of data in the primary records by EMS providers. Further, some of the collected data (e.g. OHCA aetiology) are based on a subjective clinical judgement of EMS provider, potentially leading to bias.

Currently, there is no data to be collected for the dispatcher data element domain, since the EMS dispatch service has no established telephone CPR procedures thus far.

We cannot exclude potential administrative difficulties, related with planned access and retrieval of the hospital-level data.

Complete depersonalization of data prevents contacting survivors or their relatives to retrieve information on outcomes and long-term survival.

\section{System description}

The EMS system of the Republic of Crimea is a part of the public health system with government control and budgetary funding. It is a two-tier emergency response system serving the entire population of the republic. Private ambulances are not involved in emergency dispatch process, nor in the management of OHCA. Ambulance crews $(n=144$, as of July 01,2018 ) are composed of emergency medical care physicians and/or feldshers (midlevel medical practitioners), and drivers (non-medical personnel). Both emergency physicians and feldshers are advanced life support (ALS) providers, and all ambulance vehicles are equipped for ALS. With that, ALS provision is dependent on the number of medical professionals on board: one provider - basic life support only, two providers - ALS. Advanced resuscitation skills of the EMS personnel are variable, but mostly limited to cardiac monitoring, manual defibrillation, bag-mask ventilation with oropharyngeal airways, and intravenous drugs. To date, advanced airways and intraosseous access are provided in a minority of OHCA cases. Targeted temperature management is not routinely practiced by the EMS.

The EMS dispatch service is not using standardized protocols of cardiac arrest recognition or telephone CPR. Based on a short questioning of the caller (emergency numbers are 103 and 112), the call is prioritized as urgency or emergency and an ambulance team is dispatched to the relevant address.

CPR attempt is mandatory in all cases of OHCA, excepting when primary assessment reveals clear evidence of biological death (such as rigor mortis or livor mortis) or in obviously futile cases (e.g. decapitation or incineration).[15] Do-not-resuscitate orders are not considered by the EMS. CPR is performed following the effective guidelines of the European resuscitation council. $[16,17]$ CPR effort lasts till return of spontaneous circulation (ROSC) or further resuscitation is considered to be futile (when CPR is ineffective over a period of $30 \mathrm{~min}) \cdot[15]$

\section{Results}

We hereby report the results of retrospective analysis of OHCA data collected during the period from January 01 to June 30, 2018. Considering the low volume of data, only a descriptive analysis was performed at this stage. Investigation of relationships between the variables and identification of factors, potentially influencing the outcomes of OHCA, will be done in future studies. Incidence rates for the 6 -month period were extrapolated to incidence rates per 100,000 population per year. During the period, a total of 6,391 OHCA were attended by EMS in the Republic of Crimea (unpublished data of the Crimean Republican Center for Disaster Me- 
dicine and Emergency Medical Services). Resuscitation was commenced in 196 (3.1\%) OHCA cases. Assuming the population of the republic is $1,913,731,[12]$ the incidence of OHCA with CPR attempted by EMS was found to be 20.5 per 100,000 population per year.

The mean age of OHCA patients was 65 years (standard deviation 16), median age - 65 years (range: $22-$ $94)$, and $56 \%$ ( $n=109)$ were male. Cardiac arrest mostly occurred at home $(80 \% ; n=156)$, less frequently in a street or highway $(13 \% ; n=25)$, in healthcare facilities $(5 \% ; n=10)$, public places or at workplace $(2 \% ; n=5)$.

Aetiology of OHCA was most commonly ( $n=181 ; 92 \%$ ) presumed to be medical (combining cardiac, other medical causes and cases with no obvious cause). Distribution of the cases by aetiology is shown on Figure 1. The majority of OHCA was witnessed by either the EMS or a bystander ( $95 \% ; n=186)$. Bystanders witnessed $24 \%$ $(n=47)$ cases of cardiac arrest, and of these, bystander CPR was given in $19 \%(n=9)$ : compression-only CPR five cases, chest compressions with rescue breathing three, CPR volume unknown - one. There were no cases of automated external defibrillator (AED) use (public access defibrillation is not legally permitted and AEDs are not deployed in the Crimea).

The mean EMS response time was 4 min for all OHCA cases, and 11 min when excluding EMS-witnessed cardiac arrests. $71 \%(n=139)$ cases were witnessed by EMS team. The first registered rhythm was asystole in $81 \%$ ( $n=158$ ) and was shockable (ventricular fibrillation/pulseless ventricular tachycardia) in $16 \%(n=31)$. A shock was given in $94 \%(n=29)$ of shockable OHCA. The mean time to first defibrillation was $8 \mathrm{~min}$ (12 min, when exc- luding EMS-witnessed cases; $n=15)$. The median number of shocks given was four (range: 1-11).

Airway devices were used in $91 \%(n=179)$ cases of CPR: oropharyngeal airways $-74 \%(n=145)$, supraglottic airways (laryngeal mask) - 10\% ( $n=19)$, endotracheal tube $-8 \%(n=15)$. Adrenaline and amiodarone were administered in $87 \%(n=170)$ and $12 \%(n=24)$ OHCA cases, respectively. The mean time to the first dose was 7 min (16 min, when excluding EMS-witnessed OHCA; $n=48$ ). The vascular access was most commonly peripheral intravenous $(85 \% ; n=167)$. In two cases $(1 \%)$ drugs were given intraosseously, in one case $(0.5 \%)$ - intratracheally. Thirteen of 196 patients (6.6\%) had ROSC, and 5.6\% (11/196) survived the event (i.e. had sustained ROSC until arrival at the hospital). Of them, seven (64\%) had shockable initial rhythm. Out of 11 cases of bystander-witnessed OHCA with initial shockable rhythm, two patients (18\%) gained ROSC and both survived the event (one of them received bystander compression-only (PR). Coronary reperfusion was attempted in two patients ( $1 \%$; thrombolysis before OHCA), and one of them achieved ROSC and survived the event.

We could not obtain the hospital-level data because of the lack of established administrative means to access in-hospital medical records at the moment of data collection. The proportions of missing core data variables were as follows: witnessed arrest $-1.0 \%(n=2)$, first monitored rhythm $-1.5 \%(n=3)$, drugs $-2.6 \%$ (n $=5)$, defibrillation time $-4.1 \%(n=8)$, any ROSC $-4.6 \%$ ( $n=9)$, bystander CPR $-8.2 \%(n=16)$.

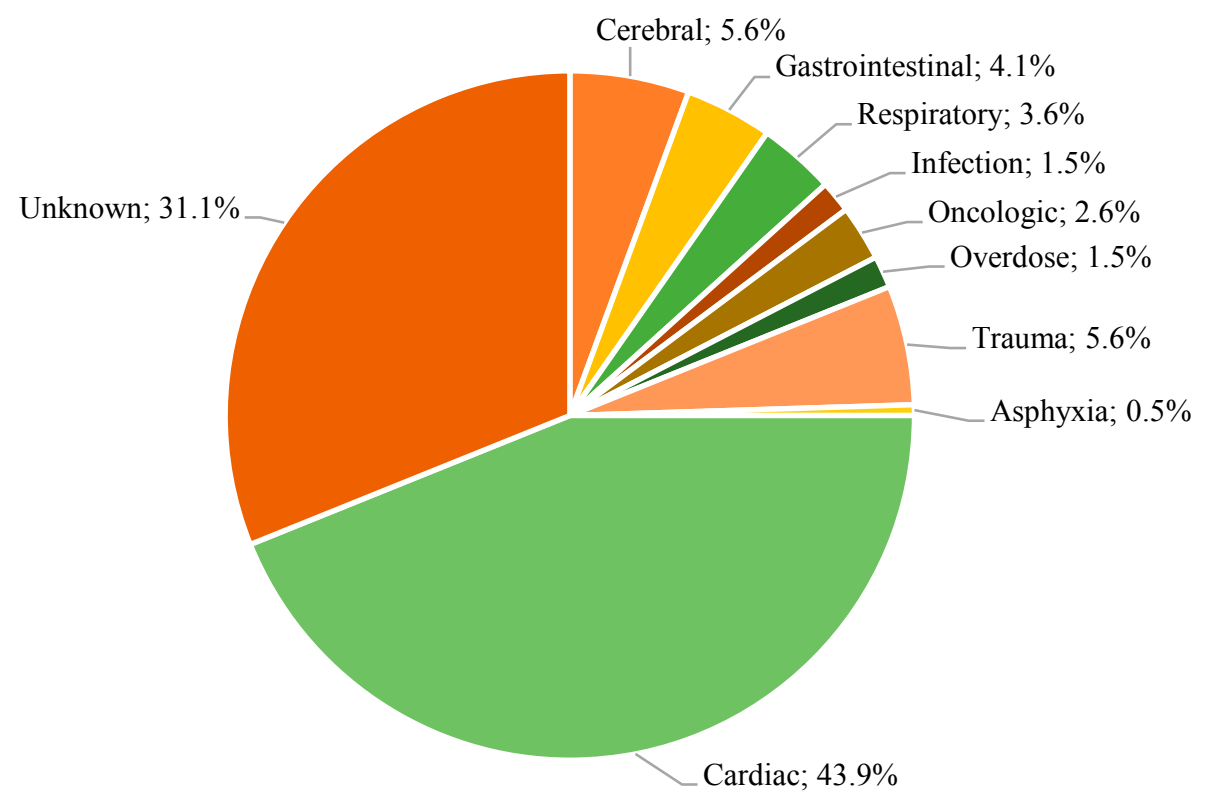

Figure 1. Distribution of the most likely primary causes of cardiac arrest 


\section{Discussion}

Few data are currently available on the OHCA epidemiology and EMS performance in the post-Soviet states. Extrapolation of the incidence of EMS-assessed $\mathrm{OH}$ CA in Europe (84 per 100,000 population),[3] suggests that about 243,600 residents of the former USSR countries may experience EMS-attended OHCA each year. With that, most post-Soviet countries have considerably lower population health and higher premature mortality than seen in Western Europe, so the real incidence of OHCA is supposed to be higher.[18] The lack of a true epidemiological picture conceals the problem, and there is a critical need for collecting and analyzing reliable data in order to improve patient care and survival from OHCA in the former Soviet states.

Cardiac arrest registries can be successfully used to perform OHCA surveillance, monitor EMS performance, prioritize cost-effective interventions focused at improving outcomes following an OHCA event and evaluate effects of these interventions.[5] Further, registries allow for comparing data within the region and with other EMS systems to identify best opportunities for enhancing pre-hospital care.[19] The comparability of the OHCA data is supported by the internationally recogni- zed Utstein guidelines on OHCA data collection and reporting.[11,14]

To our best knowledge, within the former Soviet Union territories, COHCARR represent the first effort to establish a regional registry for continuous systematic collection and analysis of OHCA data following the Utstein style methodology. Covering the whole 1.9-million population of the Republic of Crimea, it would enable to monitor trends in OHCA incidence and EMS performance in the region, identify factors influencing the outcomes, set up reasonable interventions to improve survival and evaluate their effectiveness on implementation. The registry would also promote resuscitation research. Based on the results of the 6-month data, we estimate that COHCARR will cover about 400 OHCA cases with CPR attempted by EMS annually.

In the overwhelming majority of OHCA cases $(97 \%)$ in the Republic of Crimea EMS doesn't attempt any CPR, because the patients show signs of biological death at the time of EMS arrival. Low actual number of CPR efforts may account for relatively low incidence of OHCA with CPR attempted by EMS in the region (Table 2). We suggest the low rates of CPR attempts may be associated with the prevailing inability of the bystanders to

Table 2. Key characteristics of OHCA with attempted CPR in the Republic of Crimea compared to the international data

\begin{tabular}{|c|c|c|c|c|c|}
\hline OHCA characteristics & $\begin{array}{l}\text { Republic of } \\
\text { Crimea (current } \\
\text { study) }\end{array}$ & $\begin{array}{l}27 \text { European } \\
\text { countries }^{[3]}\end{array}$ & Ireland ${ }^{[21]}$ & $\begin{array}{l}\text { USA and } \\
\text { Canada }^{[1]}\end{array}$ & $\operatorname{Japan}^{[2]}$ \\
\hline $\begin{array}{l}\text { Incidence of OHCA with } \\
\text { attempted CPR (per 100,000 } \\
\text { population-year) }\end{array}$ & 21 & 49 & 39 & $\mathrm{n} / \mathrm{d}$ & $\mathrm{n} / \mathrm{d}$ \\
\hline Age, median (years) & 65 & 70 & 67 & 66 & 76 \\
\hline Male $(\%)$ & 56 & 66 & 67 & 63 & 58 \\
\hline Presumed medical aetiology (\%) & 92 & 91 & 86 & 95 & 85 \\
\hline Initial shockable rhythm (\%) & 16 & 22 & 24 & 22 & 8 \\
\hline EMS-witnessed OHCA (\%) & 71 & 12 & 6 & 12 & 7 \\
\hline Bystander-witnessed OHCA (\%) & 24 & 54 & 54 & 38 & 34 \\
\hline $\begin{array}{l}\text { Bystander CPR (\% of bystander- } \\
\text { witnessed OHCA) }\end{array}$ & 19 & $\mathrm{n} / \mathrm{d}$ & 70 & 40 & 40 \\
\hline Any ROSC (\%) & 7 & 29 & 23 & $\mathrm{n} / \mathrm{d}$ & 9 \\
\hline Survival on arrival at hospital (\%) & 6 & 25 & 17 & $\mathrm{n} / \mathrm{d}$ & $\mathrm{n} / \mathrm{d}$ \\
\hline $\begin{array}{l}\text { Survival to hospital } \\
\text { discharge/30 days }(\%)\end{array}$ & $\mathrm{n} / \mathrm{d}$ & 10 & 6 & 10 & 5 \\
\hline
\end{tabular}

Abbreviations: CPR - cardiopulmonary resuscitation, EMS - emergency medical service, OHCA - out-of-hospital cardiac arrest, ROSC return of spontaneous circulation, $\mathrm{n} / \mathrm{d}=$ no data. 
promptly recognize the problem, activate the EMS and provide early basic CPR. When $24 \%$ of OHCA cases with attempted CPR were witnessed by a bystander, only one fifth of bystanders who witnessed cardiac arrest commenced the CPR. The low involvement of lay public in real-life CPR efforts together with limited training opportunities and poor CPR knowledge were recently shown in a survey of the Crimean population. The respondents reported lack of CPR knowledge and skiIIs to be the main barrier to perform CPR in real life.[20] Our preliminary analysis revealed very low rates of ROSC and survival to hospital admission when CPR was attempted by EMS or a bystander (Table 2). Supposedly, this may be attributable to the delayed recognition and suboptimal management of the critically ill patient, as well as late start and poor performance of resuscitation. The relatively low rate of shockable initial rhythm may argue for the assumption of a delay in the provision of appropriate care.

Alongside proving weaknesses of the pre-hospital care system, significantly lower rates of ROSC and survival to hospital arrival when compared to the international data (Table 2), suggest there is room for improvement of the outcomes from OHCA in the Crimea. In order to reduce deaths in the region, it is essential to implement a multi-level programmatic strategy following the global best practices.[22] The biggest impact on survival in spite of fewer resources can be achieved through promoting bystander CPR by increasing public awareness and community CPR training and implementing regional dispatcher-assisted CPR program.[22] Further, high-performance CPR training for EMS personnel and rapid dispatch with ongoing quality improvement processes should be considered. In turn, implementation and evaluation of effectiveness of these interventions is impossible without a reliable tool for measurement, namely the COHCARR.

\section{Conclusions}

OHCA is a major public health problem in the Crimea with high threshold for CPR commencement and very low rates of survival. The proposed Crimean out-of-hospital cardiac arrest and resuscitation registry (COHCARR) may serve as a key tool for quality improvement of pre-hospital care with the final goal of increasing survival from OHCA in the Republic of Crimea. The concept and methodology of the registry may help to establish other regional and national OHCA registries and develop resuscitation research network in the former USSR area.

\section{Acknowledgements}

The authors would like to thank Dantanarayana Visith Risira for editing the text in English language.

\section{References}

1. Daya MR, Schmicker RH, Zive DM, Rea TD, Nichol G, Buick JE, et al. Out-of-hospital cardiac arrest survival improving over time: Results from the Resuscitation Outcomes Consortium (ROC). Resuscitation 2015;91:108-15. doi: 10.1016/j.resuscitation.2015.02.003.

2. Ong ME, Shin SD, De Souza NN, Tanaka H, Nishiuchi T, Song $\mathrm{KJ}$, et al. Outcomes for out-of-hospital cardiac arrests across 7 countries in Asia: The Pan Asian Resuscitation Outcomes Study (PAROS). Resuscitation 2015;96:100-8. doi: 10.1016/j.resuscitation.2015.07.026.

3. Gräsner JT, Lefering R, Koster RW, Masterson S, Böttiger BW, Herlitz J, et al. EuReCa ONE-27 Nations, ONE Europe, ONE Registry: A prospective one month analysis of out-of-hospital cardiac arrest outcomes in 27 countries in Europe. Resuscitation 2016;105:188-95. doi: 10.1016/j. resuscitation.2016.06.004.

4. Nichol G, Rumsfeld J, Eigel B, Abella BS, Labarthe D, Hong $Y$, et al. Essentials features of designating out-of-hospital cardiac arrest as a reportable event. Circulation 2008;117:2299-308.

5. McNally B, Robb R, Mehta M, Vellano K, Valderrama AL, Yoon PW, et al. Out-of-hospital cardiac arrest surveillance Cardiac Arrest Registry to Enhance Survival (CARES), United States, October 1, 2005-December 31, 2010. MMWR Surveill Summ 2011;60(8):1-19.

6. McCauley M, Dewdney JC, Conquest R, Pipes RE. Soviet Union. Encyclopædia Britannica. (Accessed 03 December 2019, at https://www.britannica.com/place/Soviet-Union)

7. Wikipedia contributors. Post-Soviet states. Wikipedia, The free encyclopedia. (Accessed 03 December 2019, at https:// en.wikipedia.org/wiki/Post-Soviet_states)

8. Shumatov VB, Kouznetsov VV, Lebedev SV. Effective cardio-pulmonary pesuscitation on pre-hospital stage: basic elements, experience of introduction. Tikhookeanskiy meditsinskiy zhurnal 2006;1:81-4. (Russian)

9. Milin VA, Ivanova AA. Experience of the heart resuscitation at the pre-hospital stage. Tikhookeanskiy meditsinskiy zhurnal 2007;1:90-1. (Russian)

10. Birkun AA, Glotov MA. Epidemiological features of out-of-hospital cardiac arrest: evidence from particular administrative centre in Russian Federation. Anesteziol Reanimatol 2017;62(2):113-7. (Russian)

11. Perkins GD, Jacobs IG, Nadkarni VM, Berg RA, Bhanji F, Biarent $\mathrm{D}$, et al. Cardiac arrest and cardiopulmonary resuscitation outcome reports: update of the Utstein Resuscitation Registry Templates for Out-of-Hospital Cardiac Arrest: a statement for healthcare professionals from a task force of the International Liaison Committee on Resuscitation (American Heart Association, European Resuscitation Co- 
uncil, Australian and New Zealand Council on Resuscitation, Heart and Stroke Foundation of Canada, InterAmerican Heart Foundation, Resuscitation Council of Southern Africa, Resuscitation Council of Asia); and the American Heart Association Emergency Cardiovascular Care Committee and the Council on Cardiopulmonary, Critical Care, Perioperative and Resuscitation. Circulation 2015;132(13):1286300. doi: 10.1161/CIR.0000000000000144.

12. Directorate of the Federal State Statistics Service of the Republic of Crimea and Sevastopol. Official statistics. Republic of Crimea. Population. Federal State Statistics Service. (Accessed 03 December 2019, at http://crimea.gks.ru/ wps/wcm/connect/rosstat_ts/crimea/ru/statistics/stat_ Crimea/population) (Russian)

13. Federal State Statistics Service. Population. Population census in the Crimean federal district. Federal State Statistics Service. (Accessed 03 December 2019, at http:// www.gks.ru/free_doc/new_site/population/demo/perepis_krim/tab-krim.htm) (Russian)

14. Jacobs I, Nadkarni V, Bahr J, Berg RA, Billi JE, Bossaert L., et al. Cardiac Arrest and Cardiopulmonary Resuscitation Outcome Reports: Update and Simplification of the Utstein Templates for Resuscitation Registries: A Statement for Healthcare Professionals From a Task Force of the International Liaison Committee on Resuscitation (American Heart Association, European Resuscitation Council, Australian Resuscitation Council, New Zealand Resuscitation Council, Heart and Stroke Foundation of Canada, InterAmerican Heart Foundation, Resuscitation Councils of Southern Africa). Circulation 2004;110:3385-97.

15. Federal Law of the Russian Federation dated Nov 21, 2011 No. 323-FZ (revised Aug 03, 2018) "On fundamental principles of healthcare for citizens of the Russian Federation". Legislation of the Russian Federation. (Accessed 03 December 2019, at https://fzrf.su/zakon/ob-ohrane-zdorovya-grazhdan-323-fz) (Russian)
16. Perkins GD, Handley AJ, Koster RW, Castrén M, Smyth MA, Olasveengen T, et al. European Resuscitation Council Guidelines for Resuscitation 2015: Section 2. Adult basic life support and automated external defibrillation. Resuscitation 2015;95:81-99. doi: 10.1016/j.resuscitation.2015.07.015.

17. Soar J, Nolan JP, Böttiger BW, Perkins GD, Lott C, Carli P, et al. European Resuscitation Council Guidelines for Resuscitation 2015: Section 3. Adult advanced life support. Resuscitation 2015;95:100-47. doi: 10.1016/j.resuscitation.2015.07.016.

18. Trends in health systems in the former Soviet countries. Rechel B, Richardson E, McKee M, editors. Copenhagen (Denmark): European Observatory on Health Systems and Policies; 2014 (Accessed 03 December 2019, at http://www.euro.who.int/__data/assets/pdf_file/0019/261271/Trends-in-health-systems-in-the-former-Soviet-countries.pdf)

19. McNally B, Stokes A, Crouch A, Kellermann AL; CARES Surveillance Group. CARES: Cardiac Arrest Registry to Enhance Survival. Ann Emerg Med 2009;54(5):674-83.e2. doi: 10.1016/j.annemergmed.2009.03.018.

20. Birkun A., Kosova Y. Social attitude and willingness to attend cardiopulmonary resuscitation training and perform resuscitation in the Crimea. World J Emerg Med 2018;9(4):237-48.

21. Masterson S, Cullinan J, McNally B, Deasy C, Murphy A, Wright $P$, et al. Out-of-hospital cardiac arrest attended by ambulance services in Ireland: first 2 years' results from a nationwide registry. Emerg Med J 2016;33(11):776-81. doi: 10.1136/emermed-2015-205107.

22. Resuscitation Academy. 10 steps for improving survival from sudden cardiac arrest. 2018. (Accessed 03 December 2019, at http://www.resuscitationacademy.org/downloads/ebook/TenStepsforlmprovingSurvivalFromSuddenCardiacArrest-RA-eBook-PDFFinal-v1_2.pdf) 